\title{
TERAPI DZIKIR UNTUK MENINGKATKAN KETENANGAN HATI PADA PENGGUNA NAPZA
}

\author{
Olivia Dwi Kumala1 \\ Ahmad Rusdi \\ Rumiani \\ Program Studi Psikologi Profesi(S2), Universitas Islam Indonesia, Yogyakarta
}

\begin{abstract}
Drug users under rehabilitation and substance withdrawal frequently feel fear of their future and being rejected by society and family, and guilty to themselves and God. Such condition then leads the drug users to feel the negative emotions and discomfort. This research was conducted to observe the effectiveness of dhikr therapy to enhance the sobriety of drug users undergoing rehabilitation. Eight former drug users were involved in this study and divided into two groups: the experimental group $(n=4)$ and the control group $(n=4)$. The study design used was a pre-test posttest control group design and measured three times (pre-test, post-test, and follow-up for two weeks). The measuring instrument used in the study was Tatmain al-Qulüb (TQS) by Rusdi (2018) in which it was compiled based upon the aspects in sobriety. The results of this study showed a significant change in sobriety among the drug users after being given dhikr therapy.
\end{abstract}

Key words: dhikr therapy, sobriety, drug users

\begin{abstract}
ABSTRAK: Ketika melakukan rehabilitasi dan putus zat, pengguna NAPZA sering merasakan kekhawatiran akan masa depan yang terjadi, takut akan ditolak oleh masyarakat serta keluarga, adanya perasaan bersalah pada diri sendiri dan kepada Allah. Kekhawatiran ini menyebabkan pengguna NAPZA merasakan emosi negatif serta adanya perasaan tidak nyaman. Penelitian ini dilakukan untuk melihat efektivitas dari terapi dzikir untuk meningkatkan ketenangan hati pada pengguna NAPZA yang sedang melakukan rehabilitasi. Delapan mantan pengguna NAPZA terlibat dalam penelitian ini. Subjek terbagi menjadi dua kelompok yaitu kelompok eksperimen $(n=4)$ dan kelompok kontrol $(\mathrm{n}=4)$. Rancangan penelitian yang digunakan adalah pre-test post-test control group design dan diukur sebanyak tiga kali (prates, pasca tes, dan tindak lanjut selama dua minggu). Alat ukur yang digunakan dalam penelitian adalah Tatmain al-Qulūb (TQS) oleh Rusdi (2016) yang disusun berdasarkan aspek-aspek ketenangan hati. Hasil dari penelitian ini menemukan bahwa terdapat perubahan peningkatan yang signifikan terhadap ketenangan hati pada pengguna NAPZA setelah diberikan terapi dzikir.
\end{abstract}

Kata kunci : terapi dzikir, ketenangan hati, pengguna NAPZA

\footnotetext{
${ }^{1}$ Korespondensi mengenai artikel dapat melalui; oliviadwikumala@gmail.com
} 
Penyalahgunaan NAPZA merupakan salah satu fenomena sosial yang paling berbahaya pada zaman sekarang ini. Meskipun sifatnya berbahaya, penyalahgunaan obat ini tetap mudah didapati dan dikonsumsi. Hawari (2006) menjelaskan bahwa yang dimaksud dengan penyalahgunaan NAPZA adalah penggunaan NAPZA di luar indikasi medis, tanpa petunjuk atau resep dokter, sedangkan yang dimaksud ketergantungan NAPZA adalah penyalahgunaan NAPZA yang disertai dengan adanya toleransi dan gejala putus zat (withdrawal symptom). Zat yang sering disalahgunakan memiliki efek ketergantungan atau kecanduan pada penyalahguna dan menimbulkan kendala dalam fungsi sosial. Termasuk dalam kategori zat yang sering disalahgunakan adalah narkotika (opiat, ganja dan kokain), psikotropika (zat penenang, halusinogenika, psikostimulant) dan zat adiktif lainnya.

Selain itu ketergantungan zat atau obat menunjukkan kondisi yang parah dan sering dianggap sebagai penyakit. Seseorang yang ketergantungan zat akan mengalami gejala putus zat, hal ini terjadi karena kebutuhan biologik terhadap obat. Gejala putus zat merupakan adanya tanda ketergantungan fisik akibat dari ketergantungan zat obat (Jenny, 2008). Adanya ketergantungan obat yang disalahgunakan dapat menimbulkan perilaku yang menyimpang di aspek kehidupan sosial, sehingga mengakibatkan berbagai macam bahasa dan kerugian seperti, menurunnya kepribadian secara drastic berubah menjadi pemurung, pemarah bahkan melawan terhadap siapapun. Seseorang dengan ketergantungan obat memiliki dampak pada pola piki terhadap nilai-nilai dan norma-norma masyarakat, hukum dan agama.
Kecemasan merupakan kekhawatiran pada objek yang tidak jelas yang dimanifestasikan dengan perubahan fisik dan psikologis pada individu yang mengalaminya. Kecemasan yang dirasakan penggunaan narkoba merupakan hasil dari pemikiran dan keyakinannya bahwa ia tidak dapat bertahan menghadapi stres tanpa bantuan narkoba. Keyakinan ini membuat pengguna narkoba memiliki tingkat toleransi stres yang rendah dan sering kali terjerumus pada penggunaan narkoba berulang atau relaps. Seperti penelitian yang dilakukan oleh Syuhada (2012) kecemasan merupakan salah satu faktor internal yang menyebabkan pengguna narkoba mengalami relaps. Data yang diambil dari BNN menunjukkan tahun 2007 tingkat relaps sebesar $95 \%$ sedangkan pada tahun 2008 mencapai 90\% (Syuhada,2015).

Berdasarkan hasil wawancara yang telah peneliti lakukan terhadap tiga orang residen mengatakan bawah perasaan yang dirasakan yaitu adanya ketakutan dan kekhawatiran akan kehidupan yang akan datang. Saat ini residen sedang dalam proses penyembuhan disalahsatu rumah milik konsultan drug addiction yaitu Jogja Care House. Residen merasakan kekhawatiran tidak akan diterima oleh lingkungan sosial setelah nantinya kembali ke lingkungan rumah. Residen juga merasa akan mendapatkan penilaian yang buruk dari masyarakat. Setelah itu residen merasakan adanya perasaan yang mengganggu yang menyebabkan menjadi sering was-was dan keadaan fisik yang terasa sering letih yang menyebabkan menjadi tidak adanya ketertarikan untuk melakukan aktivitas. Perasaan yang mengganggu ini merupakan perasaan sedih, takut, kecewa akan diri sendiri, serta penyesalan. Adanya perasaanperasaan negatif tersebut menyebabkan emosi residen menjadi tidak stabil yang menyebabkan residen cenderung merasa tidak nyaman dengan perasaan yang dirasakan. 
Emosi pecandu narkoba ketika berbicara terkait peristiwa yang berhubungan dengan gejala putus zat atau proses relapse individu merasakan adanya reaksi tubuh dan diakhiri dengan afek negatif seperti marah, sedih dan takut. Selain itu, para pengguna NAPZA juga sering diliputi oleh perasaan-perasaan bersalah kepada diri, keluarga, masyarakat, komunitas maupun kepada Tuhan (Rosydah \& Nurdibyanandaru, 2010). Di dalam alQur'an banyak ditemui ayat-ayat yang berhubungan dengan dinamika kejiwaan manusia yang secara teoritik dapat dijadikan dasar acuan psikoterapi untuk mengatasi kecemasan. Al-Qur'an menawarkan solusi bagi jiwa yang sedang cemas untuk mendapatkan ketenangan, baik melalui bacaan maupun tulisan yang diambil dari alQur'an. Berbagai ayat al-Qur'an juga banyak yang memuat tuntutan bagaimana menghadapi permasalahan hidup tanpa rasa cemas.

Mendengarkan dan membaca alQur'an dapat menenangkan hati seseorang, sebagaimana diterangkan dalam al-Qur'an (yaitu) orang-orang yang beriman dan hati mereka menjadi tentram dengan mengingat Allah. Ingatlah, hanya dengan mengingat Allah-lah hati mereka menjadi tentram (QS Al Ra'd: 28) dari ayat tersebut dengan tegas menerangkan bahwa ketenangan hati dapat dicapai dengan mengingat Allah (Jalaluddin, 2009).

Dzikir merupakan suatu upaya untuk mendekatkan diri kepada Allah dengan cara mengingatNya. Dzikir juga merupakan suatu cara mengingat nikmatnikmat Allah. Dzikir juga memiliki pengertian mengingat Allah dalam setiap waktu, takut dan berharap hanya kepadaNya, merasa yakin bahwa diri manusia selalu berada di bawah kehendak Allah dalam segala hal dan urusannya (AshShiddieqy, 2001). Dzikir membantu individu membentuk persepsi yang lain selain ketakutan yaitu keyakinan bahwa stressor apapun akan dapat dihadapi dengan baik dengan bantuan Allah. Saat individu membiasakan dzikir, ia akan merasa dirinya dekat dengan Allah, berada dalam penjagaan dan lindunganNya kemudian akan membangkitkan percaya diri, kekuatan, perasaan aman, tenteram dan bahagia (Najati, 2005). Dzikir akan membuat seseorang merasa tenang sehingga kemudian menekan kerja system syaraf simpatetis dan mengaktifkan kerja system syaraf parasimpatetis (Saleh, 2010).

Salah satu bacaan dzikir Astagfirullahaladzim menurut Yurisaldi (2010) kalimat yang mengandung huruf jahr, seperti kalimat tauhid dan istighfar, akan meningkatkan pembuangan karbondioksida dalam paru-paru. Manfaat lainnya disebutkan oleh Rasulullah saw "barangsiapa senantiasa beristighfar, niscaya Allah akan memberikan jalan keluar dari setiap kesulitan, memberikan kelapangan dari kesusahan dan memberi rezeki kepadanya dari arah yang tak disangka-sangka" (HR. Abu Daud dan Ibnu Majah). Dari hadits tersebut dapat diambil pelajaran bahwasanya berdzikir terutama membaca istighfar memiliki keutamaan disisi Allah. Oleh karenanya peneliti ingin menggunakan terapi dzikir istigfar sebagai dzikir utama dalam penelitian ini.

\section{METODE PENELITIAN}

\section{Rancangan Penelitian}

Penelitian ini menggunakan metode kuasi eksperimen dengan pretest-posttest control grup design. Pengambilan data prates $\left(\mathrm{Y}_{1}\right)$ dilakukan pada kelompok subjek yang akan diikutsertakan dalam intervensi (X) dan pengambilan data pasca tes $\left(\mathrm{Y}_{2}\right)$ dilakukan setelah intervensi selesai dilaksanakan. Pengambilan data tindak lanjut dilakukan minimal dua minggu setelah intervensi diberikan $\left(\mathrm{Y}_{3}\right)$.

\section{Subjek Penelitian}

Subjekdalam penelitian ini adalah pengguna napza yang melakukan rehabilitasi di Jogja Care House. Subjek akan dipilih berdasarkan kriteria berikut ini: (1) laki-laki, (2) beragama islam, (3) tingkat pendidikan yang setara, (4) umur, (6) sudah melewati tahap medis (detoksifikasi), dan (6) memiliki skor ketenangan hati yang rendah hingga sedang. Subjek akan dibagi menjadi dua kelompok. Kelompok pertama, yang memiliki skor ketenangan hati yang 
sedang. Kelompok kedua adalah yang memiliki skor ketenangan hati yang rendah hingga sedang. Kedua kelompok kemudian dibagi rata untuk kemudian dibagi lagi ke dalam kelompok eksperimen dan kelompok kontrol, sehingga komposisi subjek dalam kelompok eksperimen dan kontrol seimbang.

\section{Metode Pengumpulan Data}

Variabel ketenangan hati diukur dengan menggunakan skala ketenangan hati dari Rusdi, dkk (2018). Skala ketenangan hati terdiri dari dua aspek yaitu al-sukun yang berarti kedamaian dan al-yaqin yang artinya keyakinan. Aspek al-sukun diwakili oleh 4 aitem, sedangkan aspek al-yaqin diwakili oleh 3 aitem, sehingga total item dalam skala adalah 7 buah item. Peneliti menggunakan metode rating scale dengan memberikan 6 alternatif jawaban, bergerak dari 1-6, dimana semakin mendekati angka 1 maka semakin tidak sesuai dengan diri subjek, sedangkan jika semakin mendekati angka 6 maka sikap tersebut semakin sesuai dengan diri subjek.

\section{Prosedur Intervensi}

Modul terapi dzikir yang digunakan dalam intervensi ini dirancang oleh peneliti dengan mengacu kepada aspek-aspek dzikir yaitu quantity, duration and solemnity serta connectivity. Adapun tahapan terapi dzikir dalam intervensi ini terdiri atas empat pertemuan. Pertemuan pertama, yaitu psikoedukasi menganai dzikir berupa pentingnya dzikir, bagaimana cara dzikir yang benar serta bacaan dan manfaat dzikir. Sesi edukasi terkait dengan permasalahan yang dialami dengan pengguna napza. Pertemuan kedua, yaitu pemahaman terkait bacaan dzikir yang akan digunakan pada intervensi yaitu kalimat istighfar (astaghfirullahaladzim wa Atubu ilaih) dan praktika dzikir. Pertemuan ketiga, memperbanyak dzikir. Fasilitator menjelaskan kepada subjek terkait waktu-waktu yang utama dalam melakukan dzikir dan meminta subjek untuk melakukan dzikir pada saat waktu-waktu tersebut. Pertemuan keempat, yaitu refleksi terkait pertemuanpertemuan sebelumnya serta melakukan posttest.

\section{Metode Analisis Data}

Metode analisis data yang digunakan dalam penelitian ini adalah analisis data kuantitatif dan kualitatif. Analisis data kuantitatif dilakukan untuk menguji hipotesis menggunakan analisis statistikk Anava Mixed Design. Tujuan dari Anava Mixed Design ini antara lain untuk mengetahui perbedaan skor dalam satu kelompok (pre vs post) menguji perbedaan skor antar kelompok (eksperimen vs kontrol). Analisis data dilakukan dengan menggunakan IBM SPSS Statistic 23.0.

\section{HASIL PENELITIAN}

\section{Hasil Analisis Deskriptif}

Penelitian ini mendeskripsikan 8 orang subjek penelitian yang terdiri dari 4 subjek dari kelompk eksperimen dan 4 subjek dari kelompok kontrol. Deskripsi data yang diperoleh berdasarkan hasil dari prates, pasca tes 1 dan pasca tes 2 merupakan skor tingkat ketenangan hati pada pengguna NAPZA di Jogja Care House. Berikut tabel dari ringkasan data penelitian secara keseluruhan: 
Tabel 1. Hasil Analisis Deskriptif

\begin{tabular}{cccc}
\hline Keterangan & Pretes & Post test & Follow up \\
\hline Subjek Eksperimen & 17,50 & 34,25 & 32,00 \\
1. BB & 17 & 33 & 34 \\
2. MR & 14 & 36 & 34 \\
3. RAP & 19 & 35 & 29 \\
4. FRA & 20 & 33 & 31 \\
\hline Subjek Kontrol & 20,50 & 21,50 & 25,25 \\
5. BR & 15 & 19 & 20 \\
6. BL & 24 & 23 & 25 \\
7. KP & 20 & 21 & 23 \\
8. LH & 23 & 23 & 23 \\
\hline
\end{tabular}

$\eta p 2=.736, p=.000$, Power $=.968$

Berdasarkan pada tabel di atas menunjukkan bahwa terdapat peningkatan skor ketenangan hati pada kelompok eksperimen dan kelompok kontrol. Pada kelompok eksperimen, perubahan skor ketenangan hati setelah diberikan perlakuan sebanyak 16,75. Akan tetapi setelah intervensi selesai dilakukan, skor ketenangan hati pada kelompok eksperimen mengalami penurunan sebanyak 2,25. Selanjutnya efek yang dihasilkan oleh pelatihan terhadap kelompok eksperimen didapat nilai $p=0,000(p<0.05)$ dengan efek pelatihan 0,736 atau sebesar $73 \%$. Sehingga dapat disimpulkan bahwa terapi zikir yang dibeirkan kepada kelompok eksperimen memberikan pengaruh yang signifikan terhadap ketenangan hati. Pada skor power kelompok eksperimen mendapatkan nilai $0,968(>0,3)$ yang artinya terapi dzikir yang dilakukan memiliki kekuatan yang sangat signifikan.

Berdasarkan pada tabel kelompok kontrol menunjukkan bahwa kelompok kontrol mengalami peningkatan pada skor ketenangan hati meskipun tidak diberi perlakuan. Perubahan skor pada post test yaitu 1. Selanjutnya pada skor follow up kelompok kontrol mengalami peningkatan skor sebanyak 3,75. Hal ini menunjukkan bahwa terdapat perubahan yang signifikan terhadap kelompok kontrol meskipun tidak diberikan perlakuan.

\section{Hasil Uji Normalitas}

Uji normalitas bertujuan untuk mengetahui normal atau tidaknya distribusi sebaran skor subjek pada variabel yang akan dianalisis. Apabila distribusi sebaran normal, maka subjek penelitian dapat mewakili populasi yang ada. Sebaliknya apabila sebaran tersebut tidak normal, maka subjek penelitian tidak dapat mewakili keadaan populasi yang sebenarnya dan tidak dapat digeneralisasikan pada populasi tersebut. Hasil uji normalitas dari skala prates ketenangan hati diperoleh nilai $p=0,752(p>0,05)$ yang berarti jika nilai $p$ lebih besar dari 0,05 maka sebaran data tersebut dikatakan normal.

\section{Hasil Uji Hipotesis}

Hipotesis yang diajukan dalam penelitian ini yaitu adanya pengaruh pemberian terapi dzikir terhadap peningkatan ketenangan hati pengguna napza pada kelompok eksperimen. Uji hipotesis dalam penelitian ini menggunakan anava repeated measurement yaitu digunakan jika akan dilakukan uji beda lebih dari dua kali pengukuran. Berdasarkan uji beda yang dilakukan terhadap kelompok eksperimen dan kelompok kontrol diperoleh nilai $p$ yaitu $0,003(p<0,05)$ yang artinya skor yang diperoleh singnifikan, sehingga hipotesis yang diajukan diterima. 


\section{Manipulation Check}

Manipulation check dilakukan bertujuan untuk melihat apakah tingkat dzikir masing-masing subjek termanipulasi atau tidak setelah diberikan perlakuan dapat dilihat pada tabel berikut:

Tabel 2. Manipulation check

\begin{tabular}{|c|c|c|c|c|}
\hline Variabel & Keterangan & Pretes & $\begin{array}{l}\text { Post } \\
\text { test }\end{array}$ & $\begin{array}{l}\text { Follow } \\
\text { up }\end{array}$ \\
\hline Kualitas & Subjek & 31,00 & 51,25 & 49,00 \\
\hline \multirow[t]{5}{*}{ Dzikir } & Eksperimen & & & \\
\hline & $\mathrm{BB}$ & 17 & 33 & 34 \\
\hline & MR & 14 & 36 & 34 \\
\hline & RAP & 19 & 35 & 29 \\
\hline & FRA & 20 & 33 & 31 \\
\hline
\end{tabular}

$\eta \mathrm{p} 2=.916, p=.000$, Power $=1.000$

Berdasarkan tabel di atas, dapat dilihat bahwa kelompok eksperimen memiliki skor partial eta square 0,916 yang artinya efek terapi yang mempengaruhi kelompok eksperimen sebesar 91\% serta nilai $\mathrm{p}$ yang didapatkan yaitu sebesar 0,000 $(\mathrm{p}<0,05)$ yang artinya terdapat pengaruh yang signifikan antara tingkatan dzikir yang dimiliki oleh masing-masing peserta terhadap perubahan pada ketenangan hati kelompok eksperimen. Hal menegaskan bahwa manipulasi yang dilakukan kepada subjek penelitian berhasil. Selain itu kekuatan terapi dzikir mencapi nilai 1.000 yang artinya terapi dzikir yang diberikan kepada kelompok eksperimen memiliki kepercayaan skor yang besar. atau pengaruh yang besar.

Selain itu dilakukan analisis peraspek dilakukan untuk mengetahui apakah terdapat perubahan pada tingkat alsukun yaitu kedamaian dan al-yaqin yaitu keyakinan yang dimiliki subjek yang dirasakannya setelah diberikan terapi dzikir.

Tabel 3. Analisis aspek ketenangan hati

\begin{tabular}{llllccc}
\hline \multicolumn{1}{c}{ Aspek } & Pretes & Post test & Follow up & 1p2 & $\boldsymbol{p}$ & power \\
\hline Al-Sukun & 12,63 & 17,00 & 17,50 & 0,697 & 0,007 & 0,903 \\
Al-Yaqin & 6,38 & 10,88 & 12,13 & 0,621 & 0,003 & 0,944 \\
\hline
\end{tabular}

Berdasarkan hasil analisis yang dilakukan, dapat dilihat bahwa kedua aspek yang dimiliki perserta yaitu al-sukun (kedamaian) dan al-yaqin (keyakinan) memiliki perubahan setelah diberikan terapi dzikir. Hal ini dapat dilihat dari kolom power pada aspek al-sukun memiliki skor 0,903 yang artinya kekuatan terapi dzikir yang diberikan kepada subjek memiliki pengaruh sebesar 90\%. Efek terapi yang diperoleh sebesar 0,697 atau sebesar 69\% dengan nilai $p=0,007$ sehingga dapat disimpulkan bahwa perubahan pada aspek al-sukun (kedamaian) yang dirasakan subjek signifikan. Pada aspek al-yaqin (keyakinan) dapat dilihat skor power yang diperoleh yaitu sebesar 0,944 yang artinya kekuatan terapi yang diberikan kepada aspek al-yaqin (keyakinan) memiliki pengaruh sebesar 94\%. Efek terapi yang diperoleh subjek pada aspek al-yaqin (keyakinan) 0,621 dan nilai $p=0,003$ sehingga dapat disimpulkan bahwa meskipun efek terapi yang diperoleh cenderung lebih kecil daripada aspek alsukun (kedamaian) akan tetapi dapat memberikan peningkatan dan pengaruh yang signifikan kepada tingkat keyakinan yang dimiliki oleh subjek penelitian. 


\section{Hasil Analisis Kualitatif Secara Keseluruhan Subjek}

Berdasarkan hasil analisis yang dilakukan pada setiap subjek, dapat ditemukan bahwa awal mula semua subjek penelitian menggunakan NAPZA disebabkan oleh lingkungan pertemanan. Masingmasing subjek mengatakan bahwa subjek diberikan secara gratis untuk mencoba. Jika subjek menolak, teman-teman subjek mengatakan bahwa subjek penakut. Hal inilah yang membuat subjek tidak bisa menolak ajakan teman-temannya. Selanjutnya, setelah subjek menjadi ketagihan efek yang subjek rasakan yaitu subjek didominasi kegelisahan atau kekhawatiran yang berlebihan. Selain itu efek fisik yang subjek rasakan adalah jantung berdebar kencang, mual, susah tidur, pusing, penglihatan kabur, badan gemetaran, hingga muntah. Dampak lainnya terhadap perilaku subjek yaitu subjek melakukan seks bebas, berbohong, bolos kuliah dan mencoba untuk menggunakan NAPZA jenis lainnya.

Tumbuhnya kesadaran untuk berubah lebih baik lagi ditandai dengan adanya rasa penyesalan pada diri masingmasing subjek atas perbuatan yang sudah dilakukannya. Selain itu subjek memiliki perasaan bersalah kepada orangtua, diri sendiri maupun Allah. Adanya kekhawatiran akan masa depan menjadi salah satu faktor subjek menjadi sadar harus menjadi lebih baik lagi. Setelah mengikuti terapi dzikir, masing-masing subjek mengatakan bahwa merasakan ketenangan pada diri. Ketika melakukan dzikir, masing-masing subjek teringat akan masa lalu dan menyesali perbuatannya. Perasaan dendam serta bersalah menjadi berkurang serta kekhawatiran yang subjek rasakan menjadi hilang setelah melakukan dzikir. Selain itu subjek dapat merasakan badannya menjadi rileks serta dapat tidur dengan pulas tanpa pikiran-pikiran negatif. Subjek menjadi mampu untuk mengontrol emosi setiap melakukan dzikir. Hal ini subjek rasakan karena tumbuhnya keyakinan kepada Allah. Subjek yakin bahwa Allah maha pengampun dan menerima taubat hambanya. Selain itu itu subjek yakin bahwa semua yang terjadi atas kehendak Allah, sehingga subjek tidak perlu mengkhawatirkan hal yang membuatnya menjadi tidak nyaman.

\section{PEMBAHASAN}

Penelitian ini bertujuan untuk mengetahui terdapatnya pengaruh pemberian terapi dzikir terhadap peningkatan ketenangan hati pada pengguna NAPZA. Berdasarkan hasil penelitian yang dilakukan, ditemukan adanya perbedaan tingkat ketenangan hati pada kelompok eksperimen setelah megikuti terapi dzikir. Perbedaan tersebut dilihat berdasarkan nilai $\mathrm{p}$ dari variabel ketenangan hati yaitu $0,003(\mathrm{p}<0.05)$ yang dapat diasumsikan signifikan. Hasil penelitian ini mendukung hasil penelitian sebelumnya yang dilakukan oleh Ayu Efita Sari (2015) bahwa terapi dzikir mampu memberikan ketenangan hati secara signifikan. Keberhasilan terapi dzikir terhadap peningkatan ketenangan hati ini dikarenakan tahapan yang diberikan dalam sesi terapi mampu memberikan dampak positif terhadap faktor-faktor yang mempengaruhi maupun aspek-aspek dari ketenangan hati.

Selama terapi dzikir dilakukan, subjek diajak untuk merasakan nikmat yang diberikan oleh Allah dan kasih sayang-Nya dengan cara memunculkan harapan, menumbuhkan keyakinan, memaafkan serta menerima bahwa segala sesuatu yang telah terjadi memiliki jalan keluar. Subjek diajak untuk melihat dari sisi positif dalam melihat masa lalu serta masa depan. Selain itu peningkatan terhadap ketenangan hati yang dimiliki subjek juga dipengaruhi oleh tahapan yang diberikan kepada subjek berkaitan dengan kondisi yang sedang subjek alami saat ini. Hal ini membuat subjek dapat merasakan secara langsung manfaat dari terapi dzikir yang diberikan pada setiap pertemuannya. Faktor kedua yang mempengaruhi perubahan pada tingkat ketenangan hati subjek yaitu adanya niat serta kesungguhan yang dimiliki subjek saat mengikuti terapi dzikir.

Sebelum diberikan terapi kepada subjek, subjek sangat merasakan kekhawatiran terhadap masa depannya, selain itu kekhawatiran-kekhawatiran yang subjek rasakan berkaitan dengan perbuatan yang 
dilakukannya pada masa lalu. Hal ini menyebabkan subjek memiliki rasa bersalah terhadap diri sendiri, orangtua serta keluarga. Subjek merasa takut atas kondisi yang akan dilaluinya nanti setelah selesai melakukan rehabilitasi. Kekhawati-ran inilah yang membuat subjek merasakan tidak percaya diri, sedih serta putus asa yang berdampak terhadap ketenangan hati subjek.

Kondisi yang dialami subjek ini merupakan suatu pola pikir negatif disertai dengan perasaan gelisah dan khawatir menggambarkan subjek kurang memiliki $a l-$ sukun (kedamaian) di dalam hatinya. Seperti yang dikuetahui bahwa individu yang memiliki al-sukun di dalam hatinya akan merasa hatinya diam dan tentram (Rusdi, 2016). Selain itu keyakinan juga merupakan aspek yang terdapat pada variabel ketenangan hati yang disebut al-yaqin. Apabila seseorang tidak memiliki keyakinan di dalam dirinya maka hal tersebut akan mempengaruhi keadaan hati menjadi tidak tenang (Rusdi, 2016).

Setelah mengikuti terapi dzikir, subjek menyadari bahwa kegelisahan dan kekhawatiran yang dirasakan selama ini diakibatkan karena jauhnya hubungan dengan Allah SWT. Subjek menyadari bahwa harus memperbaiki hubungannya dengan Allah agar dapat merasakan ketenangan hati secara penuh. Kesadaran akan kesalahan yang pernah dilakukan dan jauhnya hubungan dengan Allah, menye-babkan tumbuhnya kepercayaan pada diri subjek bahwa setiap masalah yang dialami akan terlewati karena Allah selalu memberikan pertolongan kepada hamba-nya dan Allah selalu memaafkan hambanya yang bertaubat. Keyakinan yang dirasakan subjek menjadikan subjek semakin yakin dapat berubah menjadi lebih baik lagi dikemudian hari, jika memperbaiki hubungannya dengan Allah.

Berdasarkan hasil keseluruhan terapi yang dilakukan, semua subjek dapat merasakan perubahan positif pada diri masing-masing subjek. Para subjek dapat merasakan bahwa terapi dzikir yang dilakukan dapat memberikan ketenangan hati yang dirasakan subjek. Selain itu terapi dzikir dapat mengubah keyakinan yang negatif pada diri subjek berubah menjadi positif. Subjek meyakini keterlibatan Allah pada setiap masalah yang dihadapinya sehingga hal ini membuat subjek merasa yakin dan lebih tenang dalam menghadapi kondisi yang dijalaninya saat ini. Hal ini sesuai dengan pendapat al-Jurjawi (Firdaus, 2016) bahwa individu yang merasa dirinya dekat dengan Tuhan, akan timbul rasa tenang dan aman.

Adanya keyakinan kepada Allah dan perasaan tenang ketika mengingat Allah seperti yang dialami subjek menunjukkan bahwa hal tersebut merupakan gambaran ketenangan hati. Sesuai dengan yang dijelaskan oleh Rusdi (2016) bahwa ketenangan hati memiliki aspek yaitu al-yaqin (keyakinan) dan alsukun (ketenangan). Sehingga dengan tumbuhnya keyakinan kepada Allah maka subjek juga dapat merasakan ketenangan pada dirinya.

\section{SIMPULAN DAN SARAN}

\section{Kesimpulan}

Berdasakan hasil analisis data dan pembahasan yang telah dilakukan, maka dapat disimpulkan bahwa terapi dzikir efektif untuk meningkatkan ketenangan hati pada pengguna NAPZA. Secara analisis kuantitatif, terdapat peningkatan skor ketenangan hati pada pengguna NAPZA. Artinya, materi-materi yang disampaikan serta praktik dzikir yang dilakukan dapat menimbulkan perasaan tenang, damai serta menunrunkan kekhawatiran, rasa sedih serta meningkatkan keyakinan yang dirasakan subjek.

\section{Saran}

Berdasarkan hasil dari pelaksanaan dan evaluasi penelitian yang dilakukan, terdapat beberapa hal yang harus dilakukan kedepannya agar penelitian yang dilakukan dapat lebih optimal yaitu peneliti diharapkan untuk memonitoring tugas rumah yang diberikan kepada masingmasing subjek secara mandiri agar peneliti mengetahui perubahan-perubahan yang terjadi pada subjek selama tidak dilakukannya proses intervensi. Selain itu waktu untuk sesi sharing disesuaikan 
dengan jumlah subjek yang mengikuti intervensi agar setiap subjek dapat mengekspresikan emosi-emosi negatif yang dirasakan dengan optimal. Pada penelitian ini hanya mampu mengungkapkan peningkatan ketenangan hati pada pengguna NAPZA, sehingga diharapkan bagi penelitian selanjutnya dapat mengungkapkan dari aspek psikologis lain serta subjek yang memiliki kriteria berbeda.

Setelah mengetahui bahwa terapi dzikir dapat meningkatkan ketenangan hati pada pengguna NAPZA, bagi instansi yang melakukan pelayanan rehabilita diharapkan dapat membuat program yang bersifat religius untuk residen agar residen lebih dapat mendekatkan diri kepada Allah dan memperoleh ilmu agama untuk membantu residen dalam meningkatkan keyakinan bahwa dengan mendekatkan diri kepada Allah merupakan salah satu jalan keluar terbaik dari masalah yang dihadapi.

\section{DAFTAR PUSTAKA}

Al-Ghazali. (1984). Ihya Ulumuddin Bab Ajaibu QolbiTerj. Ismail Yakub. Jilid 4. Jakarta: Tirta Mas.

Anggraieni, W., N. \& Subandi. (2014). Pengaruh terapi relaksasi zikir untuk menurunkan stres pada penderita hipertensi esensial. Jurnal Intervensi Psikologi. 6 (1), 81-102.

Anshori, A. (2003). Dzikir dan kedamaian jiwa. Yogyakarta: Pustaka Pelajar.

Ash Shiddieqy, H., T., M. (2001). Falsafah hukum islam. Semarang: Pustaka Rizki Putra.

Askat, A., W. (2000). Wasiat dzikir dan doa rasulullah SAW. Yogyakarta: Kreasi Wacana.

Asmaran, A. (1992). Pengantar studi akhlak. Jakarta: Rajawali.

Asy-Sya'rani, S., A., W. (2000). Menjadi Kekasih Tuhan. Jakarta: Serambi Ilmu Semesta

Azmiyati, SR. (2014). Gambaran Pengguna NAPZA pada Anak Jalanan di Kota Semarang. Jurnal Kesehatan Masyarakat (KEMAS). 9 (2): 137-143
Beck, A.,T., Freeman, A. \& Davis, D., D. (2004). Cognitive therapy of personality disorders. New York: The Guldford Press

Beck, A., T. \& Clark, D., A. (2010). Cognitive therapy of enxiety disorder. New York: The Guilford.

Chaplin, J., P. (2006). Kamus Lengkap Psikologi. Jakarta: Raja Grafindo Persada.

Chodjim, A. (2003). Alfatihah, membuka matahari dengan surat pembuka. Jakarta: Serambi Ilmu.

Davison, G., C. \& Neale J., M. (2006). Psikologi Abnormal. Jakarta: Raja Grafindo Persada.

Durrand, M.,V \& Barlow, D., H. (2007). Intisari psikologi abnormal edisi keempat buku kedua. Yogyakarta: Pustaka Pelajar

Firdaus. (2016). Spiritualitas Ibadah sebagai jalan menuju kesehatan mental yang hakiki. Jurnal AlAdyan. 11 (1), 1-24

Frager, R. (1999). Hati dari jiwa (psikologi sufi untuk transformasi). Jakarta: Serambi Ilmu 
Hannan, M. (2014). Dzikir khafi untuk menurunkan tingkat kecemasan pada lansia. Jurnal kesehatan "Wiraraja Medika" 4 (2) 47-53

Hawari, D. (2006). Penyalahgunaan \& Ketergantungan NAZA. Jakarta: FKUI

Hawari, D. (2013). Manajemen stress cemas dan depresi. Jakarta: FKUI.

Kaplan, H., I. \& Sadock, B., J. \& Grebb, J., A. (1997). Sinopsis Psikiatri. Jakarta: Binarupa Aksara.

Kartini, K. \& Jenny, A. (1989). Hygiene Mental dan Kesehatan Mental Dalam Islam. Bandung: Mandar Maju.

Maimunah, A. \& Retnowati, S. (2011). Pengaruh pelatihan relaksasi dengan dzikir untuk mengatasi kecemasan ibu hamil pertama. Jurnal Psikologi Islam (JPI) 8 (1) 1-22

Mudzkiyyah, L. (2014). Terapi zikir alfatihah untuk meningkatkan kesejahteraan subjektif pencandu narkoba dalam masa rehabilitasi. Skripsi. Fakultas Psikologi dan Ilmu Sosial Budaya Universitas Islam Indonesia Yogyakarta.

Najati, M., U. (2005). Al-Qur'an dan psikologi (Terjemahan). Jakarta: Aras Pustaka.

Nevid. (2005). Psikologi abnormal. Jakarta: Erlangga.

Osman, A., Z. (2008). Keefektifan cognitive behavior therapy (CBT) untuk menurunkan tingkat kecemasan dan meningkatkan kualitas hidup tahanan/narapidana penyalahguna napza di rumah tahanan kelas 1 surakarta. Tesis. Program Studi Kedokteran Keluarga Pasca Sarjana Universitas Negeri Sebelas Maret Surakarta
Passer, M., M. \& Smith, R., E. (2007). Psychology: The science of mind and behavior (3 ${ }^{\text {rd }}$ ed). New York: McGraw-Hill.

Ramaiah. (2003). Kecemasan: Bagaimana mengatasi penyebabnya. Jakarta: Pustaka Obor.

Rosyidah, R., \& Nurdibyanandaru, D. (2010).'Dinamika emosi pecandu narkotika dalam masa pemulihan. Fakultas Psikologi Universitas Airlangga Surabaya Insan. 12 (2) 113 - 118.

Rusdi, A. (2016). Efektivitas Salat Taubat dalam Menigkatkan Ketenangan Jiwa. Laporan Penelitian. Yogyakarta. Program Studi Magister Psikologi Profesi Fakultas Psikologi dan Sosial Budaya Universitas Islam Indonesia.

Safaria, T \& Saputra, N., E (2009). Manajemen emosi sebuah panduan cerdas bagaimana mengelola emosi positif dalam hidup anda. Jakarta: Bumi Aksara.

Saleh, A. ,Y. (2010). Berdzikir untuk kesehatan syaraf. Jakarta: Zaman.

Sari, A., E. (2015). Pengaruh Pengalaman Dzikir Terhadap Ketenangan Jiwa di Majlisul Dzakirin Kamulan Durenan Trenggalek. Skripsi. Institut Agama Islam Negeri Tulungagung.

Sholeh. (2005). Tahajud Manfaat Praktis Ditinjau Dari Ilmu Kedokteran Terapi Religius. Yogyakarta: Pustaka Pelajar

Sholihah, Q. (2015). Efektivitas Program P4GN Terhadap Pencegahan Penyalahgunaan NAPZA. Jurnal Kesehatan Masyarakat (KEMAS) 9 (1) 153-159

Solihin dan Rosihon, A. (2002). Kamus Tasawuf. Bandung: Remaja Rosda Karya. 
Supratiknya. (2006). Komunikasi antar pribadi: Tinjauan psikologis. Yogyakarta: Kanisius

Syukur, A. (2007). Dzikir Menyembuhkan Kankerku. Bandung: Hikmah
Syukur, M., A. (2010) Sufi Healing (Terapi dalam Literatur Tasawuf). Walisongo Semarang: DIPA IAIN Walisongo.

Yosep, I. (2013). Keperawatan Jiwa. Bandung: Refika Aditama

Yurisaldi. (2010). Berdzikir untuk kesehatan saraf. Jakarta: Zaman. 
Olivia Dwi Kumala, Ahmad Rusdi \& Rumiani 